\title{
LEARNING ANALYTICS IN THE CURRENT UNIVERSITY CONTEXT
} https://doi.org/10.47743/jopafl-2021-21-10

\author{
Ovidiu STOFOR \\ Alexandru Ioan Cuza University of Iaşi, \\ Faculty of Psychology and Education Sciences \\ Iaşi, Romania \\ ovidiu.stofor@uaic.ro
}

\begin{abstract}
The impact that technological progress has on the knowledge society has made the information that students receive come from many media channels. This aspect makes the current generation of students need decantation of them, in the educational environment, so that they can differentiate the qualitative information from the popular one, but without guarantees of quality. As learning tools have modernized and online platforms have become vital in these pandemic times, the ways in which learning analytics is qualitative have also evolved.
\end{abstract}

Keywords: Big Data Analytics, Data Mining, Learning Analytics, EDM

This Article was presented as a paper at the $13^{\text {th }}$ edition of the Annual International Conference Globalization and Higher Education in Economics and Business Administration (GEBA 2021), which was held at the Alexandru Ioan Cuza University, Faculty of Economics and Business Administration in Iasi, Romania from the $21^{\text {st }}$ to $23^{\text {rd }}$ of October 2021.

\section{Introduction}

The spectacular development of electronic technology has paved the way for computerization in many fields, with computers becoming more than just accessories. The 21st century offers us the opportunity to notice a heterogeneity of the way information is transmitted and evaluated in the education system: although we encounter more and more super-technological examples, we have the opportunity, at the same time, to notice schools where the methods of the 20th century are still used, or even earlier ones, if we consider some countries, such as those on the African continent. It would be inelegant not to notice the way in which the didactic process is carried out in some Romanian small isolated villages, long debated in the media, especially on the threshold of the beginning of a new school year. Since the beginning of the new millennium, a phrase has been established regarding the use of computers: the second literacy. And, it seems that the most appropriate term could be used for literacy in the education system itself.

The devastating impact of the COVID-19 pandemic has forced the approach to the same common denominator: online learning. Thus, information technologies have become very necessary, with a much more intense discussion about increasing investment in this field. Limited resources in low-income areas have prevented many students from gaining access to a level playing field due to the fact that teachers have had to restructure their 
classrooms based on available resources and access to technology (Prihar, et al., 2021). Learning analytics is what measures, collects, analyzes and presents data about students and their contexts, in order to understand and optimize learning and the environments in which it takes place (ElSayed, Caeiro-Rodríguez, Mikic-Fonte, \& Llamas-Nistal, 2019).

\section{The Permanent Sign of Change}

For a very long time, Romanian higher education, like the entire education system, has been under a "sign of change". But, just as astrology does not offer certainties of the fulfillment of expectations, neither what happens in this field so vital to a healthy evolution of society enjoys the fulfillment of the desideratum. Thus, an obvious impression would be that of an inertia that simulates evolution: on the one hand, teachers "do their job" according to the study norm, and on the other hand, students adapt to those requirements, but what seems to be lacking is the purpose of the purpose of such an interaction. For example, better synchronization between the labor market supply and what is done in colleges would be of real use; after all, one of the important roles of education is the preparation of man for active integration in social life, as a labor force, as a subject of social life (Buia, 2018). It is good to keep in mind the interest of higher education for high school graduates. According to INS data from 2019, just over 400,000 high school graduates chose to enroll in college in the 2018-2019 school year, a considerably smaller number than in 2008, when nearly 900,000 high school graduates opted for higher education. (Gheorghe, 2019). Since 2011, the number of those who choose to pursue undergraduate studies is less than 500,000, with a decreasing trend. In Figure 1 we graphically plotted the proportion of undergraduate students compared to master's students. However, compared to the fact that Romania's population is also declining, there is a percentage increase in the population with higher education at the country level, as seen in Figure 2. The ratio between the number of students enrolled in undergraduate education and the master one is also interesting.

Figure 1 Share of the number of undergraduate students, compared to the master's degree

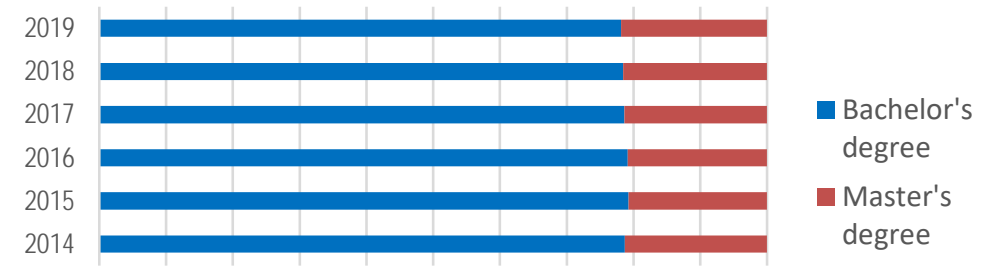

$\begin{array}{llllllllllll}0 \% & 10 \% & 20 \% & 30 \% & 40 \% & 50 \% & 60 \% & 70 \% & 80 \% & 90 \% & 100 \%\end{array}$

\begin{tabular}{|l|c|c|c|c|c|c|}
\cline { 2 - 8 } \multicolumn{1}{c|}{} & 2014 & 2015 & 2016 & 2017 & 2018 & 2019 \\
\hline - Bachelor's degree & 411.229 & 410.697 & 405.638 & 408.179 & 402.696 & 407.373 \\
\hline - Master's degree & 111.109 & 107.269 & 106.794 & 110.936 & 110.637 & 113.950 \\
\hline
\end{tabular}

Source: Processing according to INS data (INS, 2019)

There are specializations such as computer science, for example, where students come to study it because it offers great employment opportunities; to the same specialization, however, come students who already master (or believe they master) the "secrets of IT" well and need only a certification of what they already know. There are also 
specializations that offer employment niches, not necessarily in the field for which they are preparing. Thus, remaining in the area of IT jobs, foreign language graduates, in addition to their natural jobs (e.g. technical writers), manage to hire even technical ones, precisely because they have very good knowledge in that language, to the detriment of the technical training they perform at work, through intensive training. There are, however, specializations in the field of hard sciences, which offer serious premises for research, but less for employment, not being tempting for students. Also tempting are the socioeconomic specializations and quite a few of the socio-human specializations (Bobâlcă, Țugulea, \& Bradu, 2014). At the same time, employers claim that young people do not take into account the field studied when choosing a job, but rather the salary they receive (Gheorghe, 2019).

\section{Figure 2 Evolution of the number of students (bachelor, master) compared to the Romanian} population

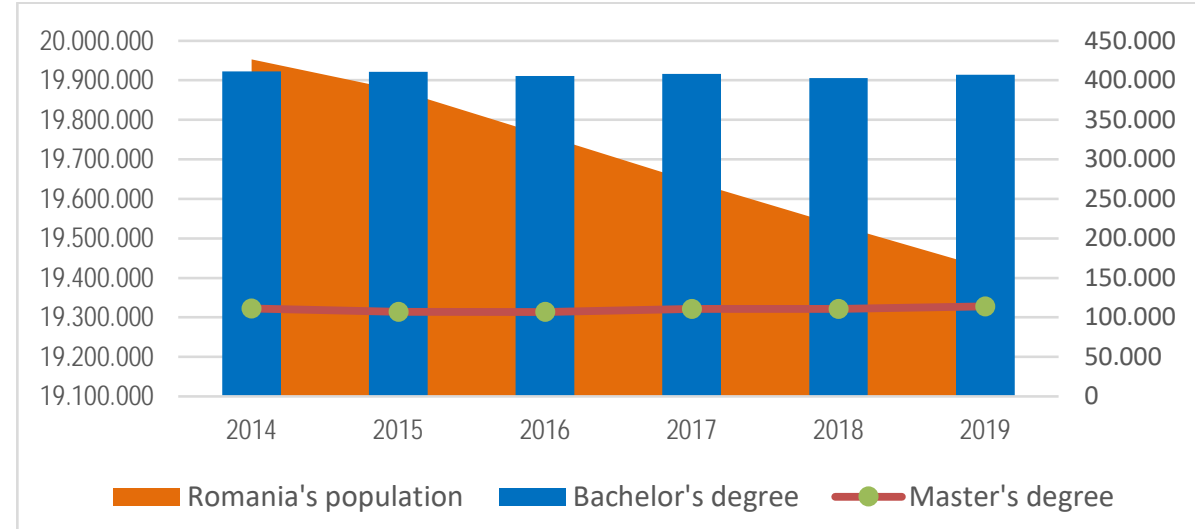

Source: Processing according to INS data (INS, 2019)

On the other hand, the way in which the candidates for higher education choose their specialization can be analyzed following the difference between the field of study chosen for the bachelor and the master, identifying a potential hypothesis of the cause for which they "change the switch"; this occurs against the background in which the reorientation at the master's level does not always bring real anchors on the labor market, especially in the conditions in which the master's degree does not have the "weight" of the bachelor's degree.

\section{Learning Analytics in the Knowledge Society}

The impact that technological progress has on the knowledge society has made the information that students receive come from many media channels. This aspect makes the current generation of students need a decantation of them, in the educational environment, so that they can differentiate the qualitative information from the popular one, but without guarantees of quality. Learning tools have modernized, and online platforms have become vital in these pandemic times; the ways in which the analysis of learning can be qualitative have also evolved. Thus, it is intuitive that the interest of researchers, but also of 
practitioners in the field of education for the analysis of learning has increased. In fact, in one study, it can be seen that the number of publications dealing with the subject of "learning analytics" has increased greatly, showing the growth of techniques, methods and applications of learning analytics (Lee, Cheung, \& Kwok, 2020), as can be seen in Figure 3 .

Figure 3 Number of studies on learning analytics published in the SCOPUS database

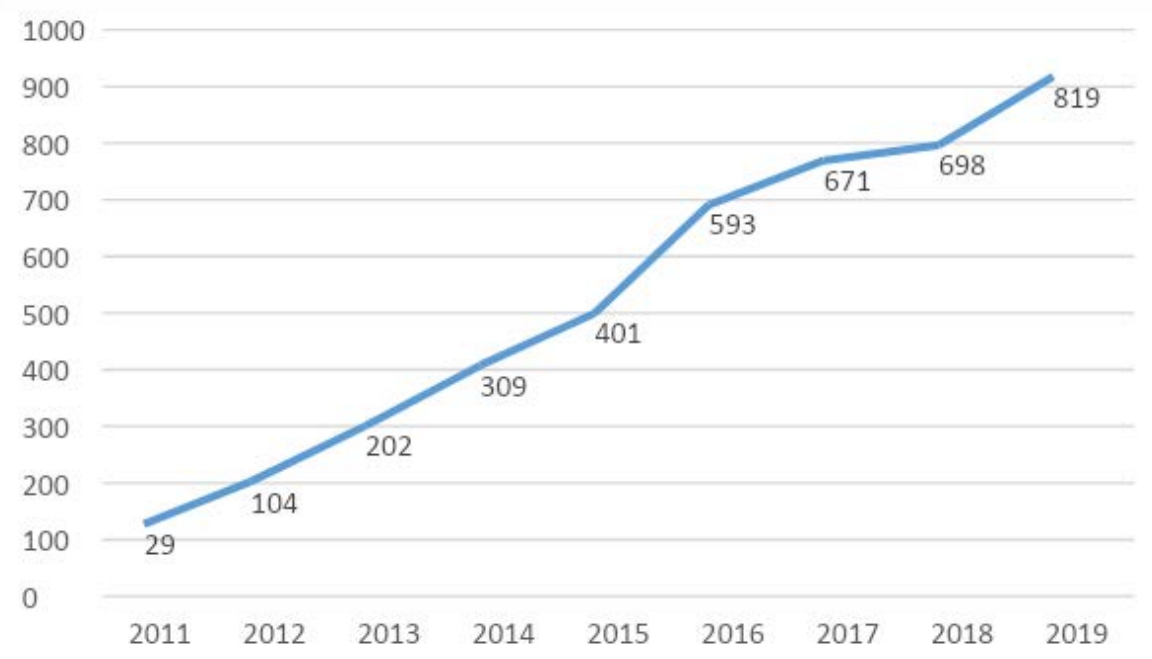

Source: Lee, Cheung \& Kwok (2020)

In order for the learning analytics to be carried out in the deepest possible way, it is necessary to support Big Data but also Data mining, both technologies representing important landmarks in making analyzes and predictions, not coincidentally involving large companies such as Oracle, IBM, Microsoft etc. Big Data provides opportunities for new statistics or the redesign of existing statistics (Braaksma, Zeelenberg, \& De Broe, 2021, p. 327). If, initially, three defining features of the big data sets were considered (volume, speed and variety), later two more were identified, of interest being the " $v$ ization” of the characteristics (all five words start with the letter V):

- $\quad$ their high volume can lead to better accuracy and more detail;

- $\quad$ their high velocity can lead to more frequent and timely statistical estimates;

- $\quad$ their high variety can provide opportunities for statistics in new areas;

- veridicity (veracity) refers to the fact that being uncertain, the data must be verified;

- the value of the data can be evaluated by analysis.

Common forms of Big Data include Internet data, transaction data, administrative data, commercially available databases, publicly available data, and paradata (data about the process by which data were collected) (McCoach, Dineen, Chafouleas, \& Briesch, 2021, pp. 628). As Schroer (2021) mentioned, Big data is becoming a transformative tool for all aspects of education, enabling educators to use large data sets to:

- draft personalized lesson plans,

- predict learning outcomes, 
- support students in identifying forms of education that suit their interests and abilities.

\section{Specific Characteristics of the Learning Analytics}

Last year has accelerated the way in which information technologies can be used in education, increasing the popularity of online education, many online learning systems, but also learning management which has been open-source. A comprehensive e-learning platform must be an integrated system of teaching, learning and management of educational content based on modern pedagogical principles and provide support for teaching and learning, testing and assessment, content management, learning monitoring and curriculum design (Şuşnea, 2012, p. 14). When it comes to education, the experience of recent years has shown us that the aspect of quality, but also the way in which it is supported to obtain qualitative results are part, as it were, of a story that involves "windmills”...

Learning analytics systems capture students' behaviors, commonly referred to as "digital breadcrumbs" that students leave throughout the system, in LMSs, as students navigate and interact with colleagues, but also with the digital space (Jones, 2019). If in a broad sense, the learning analytics investigates a large amount of data from education and presents the results of stakeholders for evidence-based decision making (Chen, 2019, p. 1957), in a brief presentation, the perspectives involved in the learning analytics represent (Drachsler \& Greller, 2011) skills (to exploit the benefits), constraints (restrictions or potential limitations for anticipated benefits, i.e. constraints related to privacy and ethics), methods (technologies, algorithms, theories), data, objectives (for setting goals to be achieved), partners (contributors and beneficiaries of learning analytics).

According to Khalil's model (2017), the learning analytics framework considers four main parts: the learning environment in which stakeholders produce data, Big Data which consists of massive amounts of data sets and large repositories of information, the analysis comprising different analytical techniques and action, where goals are achieved to optimize the learning environment. In a student-centered educational system, data on the activities of students throughout the course in which they are enrolled, processed and interpreted correctly, can provide important information to staff responsible for the proper conduct of teaching activities (educational managers, teachers, software developers, specialists in the field of psycho-pedagogy) (Şuşnea, 2012, p. 15). The development of web tracking tools has facilitated the learning analytics to enable educational institutions to gather much needed data about students' learning experiences. The development of web tracking tools has facilitated the collection of necessary information about the learning process by educational institutions.

Table 1 shows the distinction between academic analytics and learning analytics, the latter being more specific than the former. Academic analytics involves students and the institution, while learning analytics is beneficial for students, the institution, but also instructors/ educators.

Table 1 Comparison between Academic Analytics and Learning Analytics

\begin{tabular}{|c|c|}
\hline Academic Analytics & Learning Analytics \\
\hline
\end{tabular}




\begin{tabular}{|c|c|}
\hline $\begin{array}{l}\text { Academic analytics is a business intelligence } \\
\text { application in higher education. }\end{array}$ & $\begin{array}{l}\text { Learning analytics is associated with the collection, } \\
\text { measurement and analysis of student data. }\end{array}$ \\
\hline $\begin{array}{l}\text { It can be applied at three different levels: } \\
\text { institutional, regional, national/ international. }\end{array}$ & It can be coupled at course and department level. \\
\hline $\begin{array}{l}\text { The beneficiaries are the administrators, the } \\
\text { financiers of the educational authorities. }\end{array}$ & $\begin{array}{l}\text { The beneficiaries are the students and the } \\
\text { instructors. }\end{array}$ \\
\hline $\begin{array}{l}\text { It can facilitate the comparison of different } \\
\text { educational systems. }\end{array}$ & $\begin{array}{l}\text { It can help the learner and the instructor understand } \\
\text { the pattern of success or failure. }\end{array}$ \\
\hline $\begin{array}{l}\text { It can help administrators ensure optimal use of } \\
\text { resources. }\end{array}$ & It can make it easier to identify a smart resume. \\
\hline
\end{tabular}

Source: Adam, Abu Bakar, Fakhreldin, \& Abdul Majid (2018)

Therefore, the purpose of academic analysis is to support institutional, operational, and financial decision-making processes, while the overall purpose of learning analytics and EDM is to understand how students learn (Viberg, Hatakka, Bälter, \& Mavroudi, 2018). Certainly, if before the widespread use of information technologies, the learning analytics was more obvious, with the use of LMS, everything happens discreetly, to the invisible, the application taking its necessary data from clicks, navigation, in the same way that very popular social networking platforms obtain such data. In order to collect muchneeded data on students' learning experiences, the learning analytics has been fully supported by the development of web tracking tools (Czerkawski, 2015). Digital data collection considerably reduces labor and material resources, but also the time required to conduct research/ analysis. The collection of data, their processing in order to highlight trends and regularities does not ignore the human factor. Although many educational institutions have access to a lot of data about students (grades, attendance records, physical addresses and contact details, different fees) there are a number of challenges in using this data to improve the experience of pupils/ students. Thus, in 2017, according to Kenneth Green (2017), only a third of the entities stated that the investments made in data and managerial analysis had maximum efficiency; In 2018, another third of institutions systematically collect, integrate and use data from their own information systems for students (Howells, 2021).

The use of online platforms became a must-have for learning during this period when the crisis caused by the SARS-CoV-2 virus limited physical interaction. Many institutions have not been trained, so they have improvised the way they work online, without emphasizing the confidentiality of data. The learning analytics was almost in the same situation. Data collection in online learning environments is essential if they are combined with appropriate tools, theories and frameworks to model theory and guide practice, with learning analytics thus playing a very important role for learners and learning sciences. It is important what kind of data collects, manages and uses the system for analysis, who is targeted by the analysis, why the system analyzes the collected data and how the system analyzes the collected data (Chatti, et al., 2014). It is useful to mention the essential role that digital knowledge content plays in the design of learning and in the interactions of learners that appear in intelligent learning, which is defined as learning in interactive, intelligent and adapted environments, supported by advanced digital technologies and services.

Help in assessing how to achieve teaching and learning through online media comes from massively open online courses, saving costs and increasing revenue, improving 
educational outcomes, expanding the accessibility of learning materials for all by providing support for open educational resources (Khalil, 2017, p.21). Learning analytics offers the possibility to make decisions based on data about education by using quantitative methods, with the help of computer science, statistics, but also psychology.

\section{Convergence of the exploitation of large data sets for the purpose of learning analytics}

The combination of data exploitation and analysis in the educational field can mainly lead to improved students' understanding of the learning process by identifying, extracting and evaluating variables related to students' characteristics or behaviors (Baradwaj and Pal, 2012). According to the illustration in Figure 3, it is observed that the actions involving the extraction of predictive information are done using large data sets, and part of the data used in higher education provides the ground for exploring data related to the education system, through learning analytics; the analytics follows both the students and the teaching staff. Although it is observed that the overlap of EDM and the learning analytics is considerable, it is not total. Moreover, this similarity inevitably generated comparative studies between the two platforms, given the ambiguity in the definitions and objectives of the two emerging areas, so as to reach a better understanding of each area and its delimitation in subspecializations, their limits and overlaps, and their tensions and contradictions (Lemay, Baek, \& Doleck, 2021).

Figure 3 Scheme of using EDM and LA in higher education

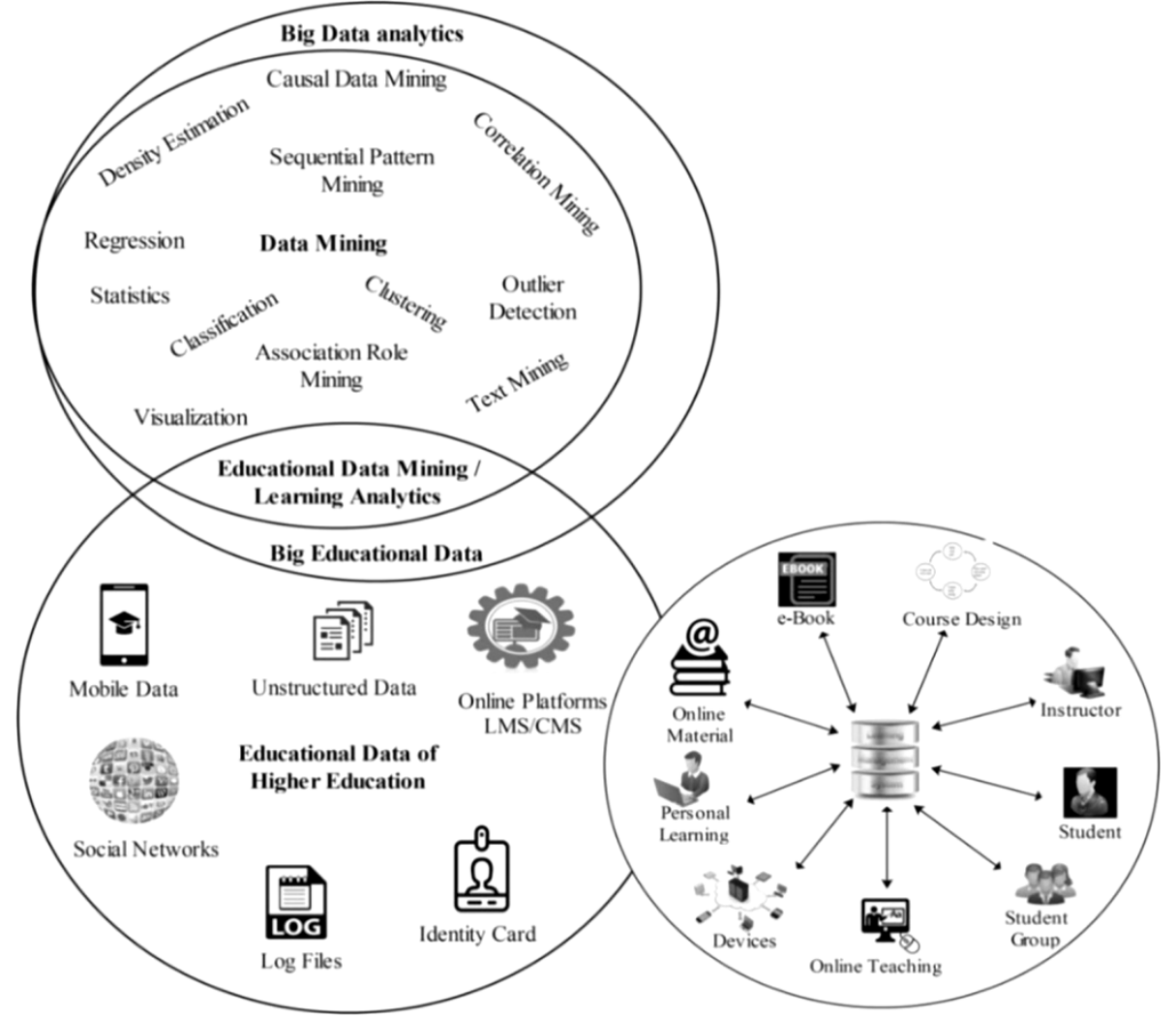

Source: Calvet Liñán \& Juan Pérez (2015) 
The graph in Figure 4 is also suggestive, where, following the example of Google Scholar, it can be seen that these fields of research have increased since the beginning of 2010, EDM starting a few years earlier. According to Aldowah, Al-Samarraie, \& Fauzy (2019), Data mining in education is at the convergence of different types of analysis: computer-aided predictive analysis, computer-based learning analytics, computer-aided visualization analysis, and computer-based behavioral analysis.

\section{Figure Evolution of EDM and LA references in Google Scholar}

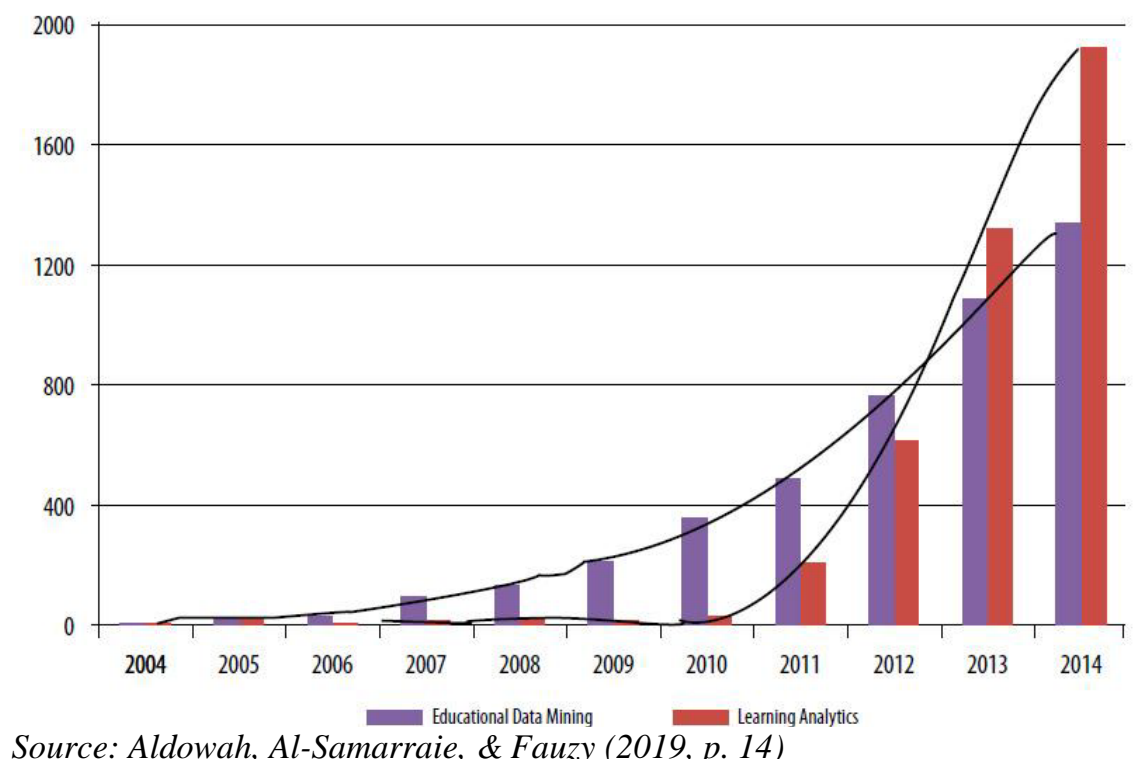

Source: Aldowah, Al-Samarraie, \& Fauzy (2019, p. 14)

Learning analytics, academic analytics and educational data extraction (EDM) are closely related research areas; they aim to support research and practice in education (Siemens \& Baker, 2012). The role of learning analytics is to improve education by providing information that otherwise cannot be obtained without the availability of data and technology today (Tsai, et al., 2020).

\section{Conclusion}

It can already be considered an axiom that information technologies have become part of everyday life of students facilitating access to information useful to the learning process. It goes without saying that it is desirable that the learning and the way in which this is done be evaluable, in order to improve its quality, if necessary. Given that, increasingly, information technologies are used for the purpose of learning, measuring, collecting, analyzing and reporting data on learners and their contexts, evaluation can be easily obtained. Apparently, this is also easy in view of the fact that, increasingly, those to whom learning is addressed are part of a dynamic generation and very attached to technology. The mismatch between user needs and the structuring of computer systems can lead to insufficient use of information, which has an important role in building trust and solidarity in an organization. Evaluation, as an operation of comparing a result with a goal, 
analyzes the situation from which it started with the one it arrived at, based on a benchmark or information and referring to criteria, in order to make a decision.

Learning analytics, as a field of research, has evolved rapidly as a necessity of supervising the quality of education, taking into account the ethical and privacy aspects. The analysis of the way in which the information technologies support the entities to increase their efficiency is the one that can determine perspectives of the progress and the qualitative growth in any field, the education being able to represent a "spearhead". The application of data mining in higher education is still in its infancy and needs a lot of attention. The results, combined with the involvement of decision-making political entities, can change education for the better.

It can be assumed that both the extraction of educational data (EDM) and Learning Analytics continue to expand, due to the relevance of the analysis based on large data sets (Big Data) performed so far; this also occurs due to the potential benefits they generate, both for students, instructors, administrators, researchers and for society in general. The use of these types of data in the learning analytics can offer the possibility to make predictions, by summarizing the data in ways that are not only easy to understand, but also useful to the owner.

\section{References}

1. Adam, K., Abu Bakar, N. A., Fakhreldin, M. A., \& Abdul Majid, M. (2018). Big Data and Learning Analytics: A Big Potential to Improve e-Learning. Advanced Science Letters. https://doi.org/10.1166/asl.2018.13028

2. Aldowah, H., Al-Samarraie, H., \& Fauzy, W. M. (2019). Educational data mining and learning analytics for 21st century higher education: A review and synthesis. Telematics and Informatics, 37, 13-49. https://doi.org/10.1016/j.tele.2019.01.007

3. Bobâlcă, C., Țugulea, O., \& Bradu, C. (2014). How are the Students Selecting their Bachelor Specialization? A Qualitative Approach. Procedia Economics and Finance, 894-902. https://doi.org/10.1016/S2212-5671(14)00553-X

4. $\quad$ Braaksma, B., Zeelenberg, K., \& De Broe, S. (2021). Big Data in Official Statistics: A Perspective from Statistics Netherlands. In C. Hill, P. Biemer, T. Buskirk, L. Japec, A. Kirchner, S. Kolenikov, \& L. Lyberg (Eds.). Hoboken, USA: John Wiley \& Sons.

5. Buia, E. (2018). Educaţia şi rolul său în societatea contemporană. Retrieved from concursurilecomper.ro: shorturl.at/qrsHX

6. $\quad$ Calvet Liñán, L., \& Juan Pérez, Á. A. (2015). Educational Data Mining and Learning Analytics: differences, similarities, and time evolution. RUSC. Universities and Knowledge Society Journal, 98-112. https://doi.org/10.7238/rusc.v12i3.2515

7. $\quad$ Chatti, M. A., Lukarov, V., Thüs, H., Muslim, A., Fahmy Yousef, A. M., Wahid, U., ... Schroeder, U. (2014). Learning Analytics: Challenges and Future Research Directions. ResearchGate.

8. Chen, W. (2019). Knowledge-Aware Learning Analytics for Smart Learning. Procedia Computer Science, 159, pp. 1957-1965. https://doi.org/10.1016/j.procs.2019.09.368

9. Czerkawski, B. (2015). When Learning Analytics Meets E-Learning. Online Journal of Distance Learning Administration, XVIII(2). Retrieved from shorturl.at/ozGMP

10. Drachsler, H., \& Greller, W. (2011). The Pulse of Learning Analytics Understandings and Expectations from the Stakeholders. International Conference Proceeding Series (ICPS). https://doi.org/10.1145/2330601.2330634

11. ElSayed, A. A., Caeiro-Rodríguez, M., Mikic-Fonte, F., \& Llamas-Nistal, M. (2019). Research in Learning Analytics and Educational Data Mining to Measure Self-Regulated Learning: A Systematic Review. The 18th World Conference on Mobile and Contextual LearningAt: Delft University of Technology. Eindhoven. 
12. Gheorghe, A. (2019). Radiografia educaţiei: câţi tineri ţin la diplomă şi urmează o facultate. Retrieved from wall-street.ro: shorturl.at/elBDV

13. Green, K. (2017). Provosts, Pedagogy and Digital Learning. Association of Chief Academic Officers. Retrieved from https://bit.ly/3eO72EB

14. Howells, E. (2021). Using Data to Better Support Students. Retrieved from Educause Review: shorturl.at/ceqy3

15. INS. (2019). Studenti si cursanti inscrisi in invatamantul universitar, pe grupe de specializari. Retrieved from http://statistici.insse.ro/

16. Jones, K. M. (2019). Learning analytics and higher education: a proposed model for establishing informed consent mechanisms to promote student privacy and autonomy. Journal of Educational Technology in Higher Education, 16(24). https://doi.org/10.1186/s41239-019-0155-0

17. Khalil, M. (2017). Learning Analytics in Massive Open Online Courses. Graz University of Technology. Retrieved from shorturl.at/elIWX

18. Lee, L.-K., Cheung, S. K., \& Kwok, L.-F. (2020). Learning analytics: current trends and innovative practices. Journal of Computers in Education, 7(1), 1-6. https://doi.org/10.1007/s40692-020-00155-8

19. Lemay, D. J., Baek, C., \& Doleck, T. (2021). Comparison of learning analytics and educational data mining: A topic modeling approach. Computers and Education: Artificial Intelligence, 2.

20. McCoach, D. B., Dineen, J. N., Chafouleas, S. M., \& Briesch, A. (2021). Reproducibility in the Era of Big Data: Lessons for Developing Robust Data Management and Data Analysis Procedures. In C. Hill, P. Biemer, T. Buskirk, L. Japec, A. Kirchner, S. Kolenikov, \& L. Lyberg (Eds.), Big Data Meets Survey Science. A Collection of Innovative Methods (pp. 627-655). Hoboken, USA: John Wiley \& Sons.

21. Prihar, E., Botelho, A., Yuen, J., Shanaj, A., Dai, Z., \& Heffernan, N. (2021). Student Engagement During Remote Learning. Companion Proceedings 11th International Conference on Learning Analytics \& Knowledge (LAK21), (pp. 49-51).

22. Schroer, A. (2021). Big Data in Education: 9 Companies Delivering Insights to the Classroom. Retrieved from Builtin.com: shorturl.at/kmJT3

23. Siemens, G., \& Baker, R. (2012). Learning analytics and educational data mining: Towards Communication and Collaboration. Proceedings of the second international conference on learning analytics \& knowledge, (pp. 252-254).

24. Şuşnea, E. (2012). Utilizarea tehnicilor data mining într-un sistem educaţional de tip e-Learning. Bucureşti: Pro Universitaria.

25. Tsai, Y.-S., Rates, D., Moreno-Marcos, P. M., Muñoz-Merino, P., Jivet, I., Scheffel, M., . . Gašević, D. (2020). Learning analytics in European higher education-Trends and barriers. Computers \& Education, 155. https://doi.org/10.1016/j.compedu.2020.103933

26. Viberg, O., Hatakka, M., Bälter, O., \& Mavroudi, A. (2018). The current landscape of learning analytics in higher education,. Computers in Human Behavior, 89, 98-110. https://doi.org/10.1016/j.chb.2018.07.027 Creative Commons Attribution - Non Commercial - No Derivatives 4.0 International License. 